\title{
Determining the Optimal Age For Selection by Modelling the Age-Related Trends in Genetic Parameters in Eucalyptus Hybrid Populations
}

\author{
By J.-M. BouveT ${ }^{\left.1),{ }^{*}\right)}$, P. Vigneron ${ }^{1)}$, E. VILlar $^{1), 2)}$ and A. SayA ${ }^{2)}$
}

(Received $21^{\text {th }}$ December 2007)

\begin{abstract}
Ten factorial mating designs using a combined total of 88 females, 107 males, 684 families and 37,206 individual trees were used to model the age-related trends in genetic parameters and genetic gain between four and 65 months in the Eucalyptus urophylla $\mathrm{x}$ grandis breeding population in Republic of Congo. Selection was either of pure species (as parents for continued breeding) or individual hybrids for commercial plantations based on clonal varieties.

The variance components were significantly different from zero for female, male and female-by-male interaction effects for volume. The age-related trends in additive, dominance and environmental variances, modelled by nonlinear functions, showed three phases corresponding to different stages of competition and growth. Male and female narrow sense heritabilities were high $\left(h^{2}{ }_{\text {Am }}=0.70\right.$ and $h^{2}{ }_{\text {Af }}=0.90$, respectively for highest estimates) compared with individual broad sense heritability $\left(h^{2}{ }_{\text {ind }}=0.45\right)$. They were modelled by polynomial functions that did not display specific trends with age.

The age-age correlations, modelled by a response surface, were higher than 0.8 after 36 months. A similar trend with age was observed for additive and total genetic effects.

Genetic gain was calculated by combining the different models. The genetic gain was higher for female than for male. Considerable gains can be achieved by clone selection. The efficiency of selection indicated an optimal age of 54 months for juvenile selection of males and females and a mature age for ortets. The trend in efficiency of selection per time unit showed that juvenile selection for volume is much more efficient than adult selection whatever the age.
\end{abstract}

Key words: Eucalyptus, volume, reciprocal recurrent selection, variance components, heritability, age-age correlation, optimal age of selection.

\section{Introduction}

Numerous breeding programmes have been implemented to provide improved germplasm in Eucalyptus, which is one of the most important genera used in plantations for pulp wood or charcoal in warm temperate, Mediterranean, and tropical climates. Many of them are based only on assessment of additive effects using open pollinated families to estimate genetic parameters and

\footnotetext{
1) Cirad Biological System Department, Research Unit "Genetic Diversity and Breeding of Forest Tree Species", TA A-39/C Campus International de Baillarguet, 34398 Montpellier Cedex, France. Phone: +33 467-593-728, Fax: +33 467-593-733.

2) UR2PI, Research Unit on the Productivity of Commercial Plantations, BP 1291 Pointe-Noire, Republic of Congo.

*) Corresponding author: JEAN-Marc BouvEt. E-Mail: jean-marc. bouvet@cirad.fr
}

genetic gain in the framework of recurrent selection schemes. Examples exist for Eucalyptus globulus in Australia (LOPEZ et al., 2001), E. globulus in Chile (SANHUEZA et al., 2002), E. nitens in Australia (TiBbits and Hodge, 1998) and in Chile (Velilla et al., 2007), E. grandis in Colombia (Osorio et al., 2003), and E. urophylla in China (WEI and BorRALHo, 1998). For the last twenty years, some eucalyptus breeding programmes have been based on inter-specific hybrids, which at many sites have shown better growth and adaptation than pure species (DE Assis, 2000; DALE and DiETERS, 2007; LEE et al., 2007). These programmes have provided numerous clonal varieties, delivered significant gains (VERRYN, 2000), and assessed the relative importance of dominance and additive effects (VOLKER, 1995; LEE et al. 2007; Retief and StANGeR, 2007). However, results on the relative importance of genetic effects are still few and new experiments are needed to improve our understanding of additive and non-additive genetic effects in hybrid populations.

The E. urophylla $\mathrm{x}$ grandis breeding programme in the Republic of Congo has been promoted for commercial plantations in the southern region of the country. Numerous clones, resulting from a reciprocal recurrent selection strategy (RRS) (VIGNERON, 1991; VIGNERON and BouveT, 1997; VIGNERON et al., 2000), are currently used to produce pulp wood. However, thanks to the large number of genetic trials, the design of the programme also offered us the opportunity to improve our understanding of the expression of both additive and nonadditive age-related effects and their consequences for genetic gain. Better assessment of trends displayed by genetic parameters (variances, heritability, correlations) with age is a key factor in calculating genetic gain and in defining the optimal age for selection.

In this study, we used a large sample of parents, families, and individual trees resulting from 10 factorial mating designs established over 15 years corresponding to the first cycle of the RRS scheme. The general goal was to determine the optimal age for the selection of parents and ortets by modelling trends in genetic selection efficiency. The specific objectives were (i) to assess the age-related changes in the magnitude of additive, non-additive, and environmental variance, (ii) to estimate the trends in age-age correlations, and (iii) to evaluate the genetic gain for parent and ortet selection.

\section{Materials and Methods}

\section{Genetic material}

Data were obtained from field trials conducted in the Republic of Congo at the UR2PI research centre "Unité 
de Recherche sur la Productivité des Plantations Industrielles du Congo" (04 $45^{\circ} \mathrm{S}, 12^{\circ} 00^{\prime} \mathrm{E}$, alt $\left.50 \mathrm{~m}\right)$. The climate is tropical humid with a mean annual temperature of $24^{\circ} \mathrm{C}$, a mean annual rainfall of $1200 \mathrm{~mm}$ (with marked between-year variation, from 500 to $2000 \mathrm{~mm}$ ) and a dry season from May to October. This study used the same plant material used for the reciprocal recurrent selection scheme for the production of hybrid clones planted in the commercial plantations in the Congo (Vigneron and Bouvet, 1997). Two species are being used in that scheme: $E$. urophylla, selected for its adaptation to climate and soil conditions, and its resistance to parasites, and E. grandis, selected for its rapid growth during the juvenile stage and its straight stem. $E$. grandis, used as the pollen parent, was sourced from the northern part of its natural range, in Queensland, Australia. The males of $E$. grandis were selected at adult stage for their growth, adaptation and stem straightness. The females of $E$. urophylla were sourced from a range of provenance trials established in the Congo from 1971 to 1986 . The first $E$. urophylla parents were selected for their abundance of flowers (in many cases they were border trees that benefited from more light) or for their early growth one or two years after planting. Progressively, E. urophylla females were selected for their growth, stem form or adaptation as adults. Selected trees of both species were grafted into seed orchards. Crosses were made by controlled pollination (BOUVET, 1982) using a factorial mating design with $E$. urophylla as females and E. grandis as males. Owing to technical problems, the mating design was not complete and not correctly balanced: for most of the mating designs, the ratio of full cells to total cells was less than $50 \%$ (see Table 1). The plants were grown in the UR2PI nursery in Pointe-Noire. The seeds were sown on a sandy substrate and the two-leaf seedlings were transferred to small containers. After three months, the seedlings had reached an average height of $40 \mathrm{~cm}$ and were ready for planting.

The hybrid families were planted at $4 \mathrm{~m} \mathrm{x} 4 \mathrm{~m}$ spacing (625 trees/ha). This is low stocking for a short rotation pulpwood crop, but this is the density used by commercial plantations and was determined by previous silvicultural research. Within each field trial, the experiment was an incomplete block design with 16-tree square plots in four replicates. To minimize edge effects, two border rows were planted around the trial plots. From 1989 to 2001, ten factorial mating designs were constructed and planted in the same zone in a single site. A total of 88 different females, 107 males, 684 fullsib families and 37,206 individuals (Table 1) were established in this first cycle of RRS.

\section{Measurements}

Circumference at breast height $(1.3 \mathrm{~m})$ and total height were used to calculate volume using a conic function. Trial measurement ceased after ortet selection (varying from 36 to 50 months old), and shoots were collected from the stumps of the "plus" trees to provide the first ramets of clones. The number of measurements varied from one trial to another (Table 1).

\section{Estimation of variance components}

Data analyses were conducted after removing outlier trees such as dwarfs (very small trees with abnormal architecture). As the mating designs were connected by only one or two parents, and because the measurements were made at different ages in the trials (Table 1), analyses of variance were performed independently for each trial. The average trend in variance was modelled using a nonlinear equation. For the analysis of each mating design, we used the following mixed model (BouVET et al., 2008):

$$
\left.\mathrm{y}_{\mathrm{ijkl}}=\mu+\mathrm{m}_{\mathrm{i}}+\mathrm{f}_{\mathrm{j}}+\mathrm{m}^{*} \mathrm{f}_{\mathrm{ij}}+\mathrm{b}_{\mathrm{k}}+\mathrm{m}^{*} \mathrm{f}^{*} \mathrm{~b}_{\mathrm{ijk}}+\mathrm{r}_{\mathrm{ijkl}} \quad \text { (model } 1\right)
$$

where $\mathrm{y}_{\mathrm{ijkl}}$ is the $\mathrm{l}^{\text {th }}$ tree in the $\mathrm{k}^{\text {th }}$ block resulting from the cross of the $i^{\text {th }}$ male in the $\mathrm{j}^{\text {th }}$ female,

$\mu$ is the overall mean,

$\mathrm{m}_{\mathrm{i}}$ is the random effect of male $\mathrm{i}$ with variance $\sigma_{\mathrm{m}}^{2}$ and an expectation of 0 ,

$f_{j}$ is the random effect of the $j^{\text {th }}$ female, with variance $\sigma_{f}^{2}$ and an expectation of 0 ,

$\mathrm{m}^{*} \mathrm{f}_{\mathrm{ij}}$ is a random effect of the male $\mathrm{i}$ by female $\mathrm{j}$ interaction with variance $\sigma^{2}{ }_{m * f}$ and an expectation of 0 ,

$b_{k}$ is the effect of the $k^{\text {th }}$ block considered as fixed,

$\left(\mathrm{m}^{*} \mathrm{f}^{*} \mathrm{~b}\right)_{\mathrm{ijk}}$ is the male-by-female-by-block interaction effect with variance $\sigma_{\text {plot }}^{2}$ and an expectation of 0 which estimates the environmental effect common to all the individuals planted in the same plot (GALLAIS, 1989),

$r_{i j k l}$ is the residual random effect with variance $\sigma_{r}^{2}$ and an expectation of 0 which estimates the confounded genetic and environmental effect common to all the individuals planted in the same plot.

The variance components were estimated using the SAS VARCOMP procedure and the REML (restricted maximum likelihood) method of the SAS/STAT ${ }^{\circledR}$ software (SAS INSTITUTE, 1990). The relationship between variance components and the quantitative genetic model was used to estimate the additive and dominance variance (GALLAIS, 1989).

$\sigma_{\mathrm{Am}}^{2}=4^{*} \sigma_{\mathrm{m}}^{2}$ is the additive variance due to the male effect,

$\sigma_{\mathrm{Af}}^{2}=4 * \sigma_{\mathrm{f}}^{2}$ is the additive variance due to the female effect,

$\sigma_{\mathrm{A}}^{2}=1 / 2\left(\sigma_{\mathrm{Am}}^{2}+\sigma_{\mathrm{Af}}^{2}\right)$ or $\sigma_{\mathrm{A}}^{2}=2 *\left(\sigma_{\mathrm{m}}^{2}+\sigma_{\mathrm{f}}^{2}\right)$ is the additive variance combining the male and female effects,

$\sigma_{\mathrm{D}}^{2}=4^{*} \sigma_{\mathrm{m}_{\mathrm{f}} \mathrm{f}}^{2}$ is the dominance variance,

$\sigma_{\text {env }}^{2}=\sigma_{\text {plot }}^{2}+\left[\sigma_{\mathrm{r}}^{2}-\left(1 / 2 \sigma_{\mathrm{A}}^{2}+{ }^{3} /{ }_{4} \sigma_{\mathrm{A}}^{2}\right)\right]$ is the environmental variance estimated by combining within-plot and between-plot environmental variance,

$\sigma_{\mathrm{G}}^{2}=\sigma_{\mathrm{A}}^{2}+\sigma_{\mathrm{D}}^{2}$ or $\sigma_{\mathrm{G}}^{2}=2 *\left(\sigma_{\mathrm{m}}^{2}+\sigma_{\mathrm{f}}^{2}\right)+4{ }^{*} \sigma_{\mathrm{m} * \mathrm{f}}^{2}$ is the total genetic variance,

$\sigma_{\text {phen }}^{2}=\sigma_{\text {A }}^{2}+\sigma_{\mathrm{D}}^{2}+\sigma_{\text {env }}^{2}$ is the total phenotypic individual variance.

Various variance ratios were analysed: $\left(\sigma_{\mathrm{D}}^{2} / \sigma_{\mathrm{A}}^{2}\right)$ is the ratio of dominance to additive variance and $\left(\sigma_{\mathrm{m}}^{2} / \sigma_{\mathrm{f}}^{2}\right)$ is the ratio of male additive to female additive variance.

\section{Calculation of correlations}

To calculate the age-age correlations, we estimated the genetic and residual variance and co-variance compo- 
nents between two ages with the SAS GLM procedure (MANOVA option) and the Type III sums of squares (SAS INSTITUTE Inc. 1990). The variance and covariance components were estimated by equating the expected mean square (calculated by the RANDOM option) to the mean square given by type III of analysis of variance (BECKER, 1984).

$\sigma_{(\text {age1, age2) }}$ being the covariance between volume at age 1 and volume at age $2, \sigma_{(\text {age1) }}^{2}$ and $\sigma_{(\text {age2) }}^{2}$ being the variance at age 1 and age 2 , three correlations can be estimated:

the male additive correlation

$$
\rho_{\text {Am(age1/age } 2)}=\frac{\sigma_{A m(a g e l, a g e 2)}}{\sigma_{A m(a g e 1)} * \sigma_{A m(a g e 2)}},
$$

the female additive correlation

$$
\rho_{A f(\text { age } 1 / \text { age } 2)}=\frac{\sigma_{\text {Af (age } 1, \text { age } 2)}}{\sigma_{A f(\text { age } 1)} * \sigma_{A f(\text { age } 2)}}
$$

the total genetic correlation

$$
\rho_{G(\text { age1iagc } 2)}=\frac{\sigma_{G(a g e l, a g e 2)}}{\sigma_{G(a g e 1)} * \sigma_{G(\text { age } 2)}}
$$

\section{Calculation of heritabilities}

$h^{2}$ Af is the narrow sense heritability based on the mean female progeny:

$$
h_{A f}^{2}=\frac{1 / 4 \sigma_{A f}^{2}}{\sigma_{f}^{2}+\frac{\sigma_{m^{*} f}^{2}}{m^{\prime}}+\frac{\sigma_{p l o t}^{2}}{b^{\prime} m^{\prime}}+\frac{\sigma_{r}^{2}}{b^{\prime} m^{\prime} n^{\prime}}}
$$

Where $\mathrm{m}$ ' is the harmonic mean of males crossed with one female, $b$ ' is the harmonic mean number of repetitions and n' is the harmonic mean number of trees per plot.

$h^{2}{ }_{\mathrm{Am}}$ is the narrow sense heritability based on the mean male progeny:

$$
h_{A m}^{2}=\frac{1 / 4 \sigma_{A m}^{2}}{\sigma_{m}^{2}+\frac{\sigma_{m^{*} f}^{2}}{f^{\prime}}+\frac{\sigma_{p l o t}^{2}}{b^{\prime} f^{\prime}}+\frac{\sigma_{r}^{2}}{b^{\prime} f^{\prime} n^{\prime}}}
$$

Where f' is the harmonic mean of females crossed with one male, b' is the harmonic mean number of repetitions and n' is the harmonic mean number of trees per plot.

$H^{2}{ }_{i n d}$ is the broad sense heritability based on individuals:

$$
H_{i n d l}^{2}=\frac{2\left(\sigma_{m}^{2}+\sigma_{f}^{2}\right)+4 \sigma_{m^{*} f}^{2}}{2\left(\sigma_{m}^{2}+\sigma_{f}^{2}\right)+4 \sigma_{m^{*} f}^{2}+\sigma_{e n v}^{2}}
$$

\section{Modelling trends in genetic parameters with age}

We used nonlinear and polynomial models to assess the general trend in variance components, variance ratio and correlations. Numerous classic models were tested using the Xlstat-Pro ${ }^{\circledR}$ version 7.5 (Addinsoft, France, Paris: www.xlstat.com). Based on the determination coefficient, we selected the following non linear model for modelling the variance components with age:

$$
\left.\sigma_{m}^{2} \text { or } \sigma_{f}^{2} \text { or } \sigma_{m m^{*} f}^{2} \text { or } \sigma_{e m,}^{2} \text { or } \sigma_{p h e n}^{2}=\frac{a}{\left(1-e^{-b}-c^{*} a g c\right.}\right) \quad(\text { model 2) }
$$

For the trends in heritability, we used a polynomial equation of degree 2 .

$$
H_{\text {ind }}^{2} \text { or } h_{A f}^{2} \text { or } h_{A m}^{2}=a+b^{*} \text { age }+c^{*} \text { age } e^{2}
$$

(model 3)

For the age-age correlation, the model was based on the response surface method (MEYERS and MonTGOMERY, 2002). The coefficients were estimated using the SAS procedure PROC RSREG (SAS INSTITUTE, 1990) to estimate a surface response. The surface we used to model the age-age correlation was as follows:

$$
\begin{aligned}
\rho_{\text {age1/age } 2}= & a+b * a g e_{1}+c * a g e_{2}+d * a g e_{1}^{2}+ \\
& e^{*} a g e_{2}^{2}+f * a g e_{2}^{*} a g e_{1}
\end{aligned}
$$

(model 4)

For the three models, an adjustment was made by weighting each estimate of the variance ratio with the number of crosses made in each mating design (Table 1). This procedure takes into account the accuracy of each estimate. The method of weighting used, the estimations of coefficients (a, b, c, d, e and f) and the calculation of associated probability for testing the significance of the model were done with the NLIN and REG procedures of the SAS software (SAS InSTITUTE, 1990).

\section{Calculation of genetic gain and selection efficiency}

Classic formulas were used to calculate the gain at the adult stage (age 2) (72 months in the case of these plantations and the corresponding improvement programme) and the correlated genetic gain by a selection at younger stages (OsoRio et al., 2003). The values of parameters over time were given by the different models [1 to 4]. In the reciprocal recurrent selection strategy, two types of selection need to be considered: the selection of parents for the intra-species recombination phase and the selection of ortets for the development of clonal varieties.

Gain, as a percent of population mean, when selecting at age 2 (age 2 rotation age, i.e., 72 months):

$$
\Delta G_{\text {age } 2}=\frac{i * H_{\text {age } 2}^{2} * \sigma_{\text {phen lage } 2}}{\text { trait mean age } 2} * 100,
$$

Gain at age 2 as a percent of population mean, when selecting at age 1 (age 1 = considered as the juvenile stage):

$$
\Delta G_{\text {agel/age } 2}=\frac{i^{*} H_{\text {age1 }} * \rho_{\text {(ageliage } 2)} * H_{\text {uge } 2} * \sigma_{\text {phentage } 2}}{\text { trait mean } n_{\text {age } 2}} * 100 \text {, (eq.5) }
$$

Where " $i$ " is the intensity of selection expressed as standard deviation (GALlAIS, 1989), $\rho_{\text {(age1-age2) }}$ is the genetic correlation between age1 and age2 (rotation age), $\mathrm{H}_{\text {age1 (age2) }}$ is the square root of the heritability at age 1 (age 2 ), $\sigma_{\text {phen/age } 2}$ is the square root of the phenotypic variance at age2.

To analyse the efficiency of juvenile selection we applied two approaches commonly used in forest tree breeding (JoHNSON et al., 1997; ADAMS et al., 2001): the efficiency of juvenile selection " $E$ " when selecting at age 1 to predict gain at age 2 defined in previous studies (Osorio et al., 2003) by: 


$$
E=\frac{\Delta G_{\text {age1/age2 }}}{\Delta G_{\text {age } 2}}
$$

and the gain efficiency per time unit " $E_{t}$ " when selecting at age 1 to predict gain at age2 (LEE et al., 2001) defined by:

$$
E_{t}=\frac{\Delta G_{\text {age } 1 / \text { age } 2}}{\Delta G_{\text {age } 2}} * \frac{a g e 2}{a g e 1},
$$

\section{Results}

\section{Growth of the Eucalyptus hybrid}

The trials were differently affected by mortality, but mortality was generally moderate after the first year and was lower than $16 \%$ at 72 months old (Table 1). At
72 months, with a density of 625 trees/ha, the mean stem volume was $150 \mathrm{dm}^{3} /$ tree. The increase in volume was moderate, (see Table 1) due to the poor sandy soils of the region. The range in volume was significant between some experiments and the two extremes at 67 months were represented by trial R90-11 with a mean individual volume $\mathrm{VI}=135.44 \mathrm{dm}^{3}$ and trial R99-2 with an individual volume $\mathrm{VI}=196.89 \mathrm{dm}^{3}$. However, we were unable to attribute this difference to the soil, climatic factors, or to the genetic performances of plant material used in the different mating designs.

\section{Trends in variances}

The analyses showed that the variances were significantly different from zero for the three genetic effects (results not shown), indicating marked variability with-

Table 1. - Main characteristics of the mating designs, age of measurement, trend in mean volume and mortality with age for each

\begin{tabular}{|c|c|c|c|c|c|c|c|c|c|}
\hline $\begin{array}{l}\text { Year of } \\
\text { planting }\end{array}$ & plan & $\begin{array}{l}\text { Full cells/total } \\
\text { cells }(\%)\end{array}$ & $\begin{array}{l}\text { Number of full- } \\
\text { sib families }\end{array}$ & $\begin{array}{l}\text { Number of } \\
\text { E. urophylla } \\
\text { females }\end{array}$ & $\begin{array}{l}\text { Number of } E \text {. } \\
\text { grandis males }\end{array}$ & $\begin{array}{l}\text { Number of } \\
\text { trees in the } \\
\text { trial }\end{array}$ & $\begin{array}{l}\text { Age at } \\
\text { measurement } \\
\text { (months) }\end{array}$ & $\begin{array}{l}\text { volume } \\
\text { (dm3) }\end{array}$ & $\begin{array}{l}\text { mortality } \\
(\%)\end{array}$ \\
\hline \multirow[t]{5}{*}{1989} & R89-20 & 37 & 50 & 15 & 9 & 2144 & 18 & 13.36 & 10.2 \\
\hline & & & & & & & 29 & 35.25 & 15.3 \\
\hline & & & & & & & 36 & 56.89 & 15.5 \\
\hline & & & & & & & 42 & 71.00 & 15.6 \\
\hline & & & & & & & 48 & 87.51 & 15.7 \\
\hline \multirow[t]{4}{*}{1990} & R90-11 & 45 & 94 & 16 & 13 & 4828 & 15 & 5.33 & 9.5 \\
\hline & & & & & & & 27 & 25.81 & 10.2 \\
\hline & & & & & & & 38 & 47.82 & 10.5 \\
\hline & & & & & & & 67 & 135.44 & 12.5 \\
\hline \multirow[t]{4}{*}{1991} & R91-7 & 60 & 38 & 9 & 7 & 2048 & 19 & 14.55 & 9.6 \\
\hline & & & & & & & 24 & 27.67 & 9.7 \\
\hline & & & & & & & 39 & 64.60 & 9.8 \\
\hline & & & & & & & 50 & 98.87 & 10.2 \\
\hline \multirow[t]{2}{*}{1992} & R92-4 & 46 & 121 & 20 & 13 & 6464 & 35 & 62.92 & 13.6 \\
\hline & & & & & & & 48 & 120.11 & 14.4 \\
\hline \multirow[t]{2}{*}{1995} & R95-7 & 15 & 126 & 29 & 29 & 6928 & 19 & 12.23 & 9.8 \\
\hline & & & & & & & 35 & 52.99 & 10.8 \\
\hline \multirow[t]{2}{*}{1996} & R96-3 & 19 & 60 & 15 & 15 & 3120 & 24 & 31.48 & 6.9 \\
\hline & & & & & & & 38 & 65.74 & 9.1 \\
\hline \multirow[t]{4}{*}{1997} & R97-5 & 27 & 72 & 7 & 18 & 4800 & 14 & 11.13 & 6.0 \\
\hline & & & & & & & 34 & 72.87 & 7.1 \\
\hline & & & & & & & 39 & 94.73 & 7.6 \\
\hline & & & & & & & 48 & 123.44 & 8.0 \\
\hline \multirow[t]{4}{*}{1999} & R99-2 & 33 & 52 & 12 & 13 & 2816 & 12 & 7.15 & 4.9 \\
\hline & & & & & & & 24 & 38.93 & 6.4 \\
\hline & & & & & & & 49 & 134.99 & 11.2 \\
\hline & & & & & & & 65 & 196.89 & 15.7 \\
\hline \multirow[t]{3}{*}{2000} & Roo-1 & 65 & 26 & 5 & 8 & 1750 & 13 & 9.08 & 4.6 \\
\hline & & & & & & & 40 & 102.30 & 10.0 \\
\hline & & & & & & & 61 & 171.74 & 12.0 \\
\hline \multirow[t]{3}{*}{2001} & R01-1 & 47 & 45 & 6 & 16 & 2308 & 24 & 42.63 & 2.9 \\
\hline & & & & & & & 40 & 99.18 & 6.7 \\
\hline & & & & & & & 48 & 117.92 & 7.8 \\
\hline \multicolumn{3}{|l|}{ total } & 684 & $88^{(1)}$ & $107^{(1)}$ & 37206 & & & \\
\hline
\end{tabular}
plan.

(1) This is the number of different females and males used in the mating design. This number is smaller than the column total because some males and females are repeated in several mating designs. 
$a: \sigma_{m}^{2}-$ Male effect
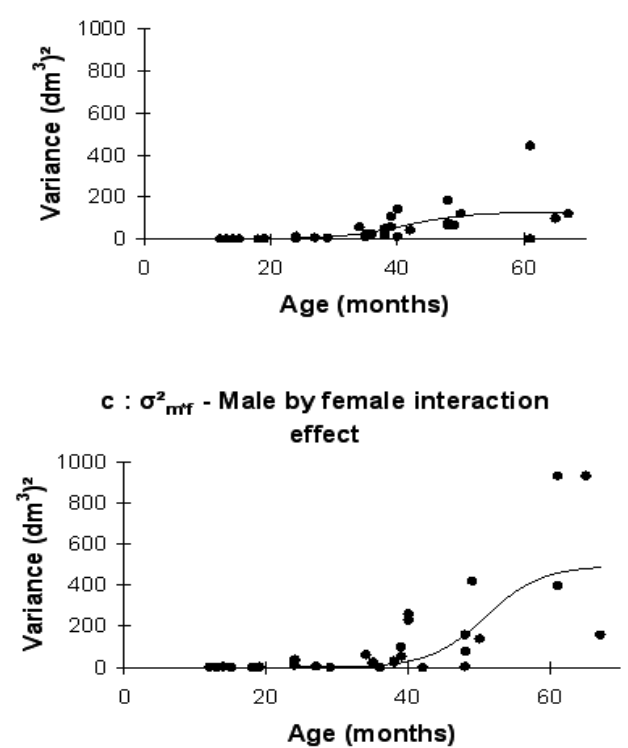

b : $\sigma_{f}^{2}-$ Female effect

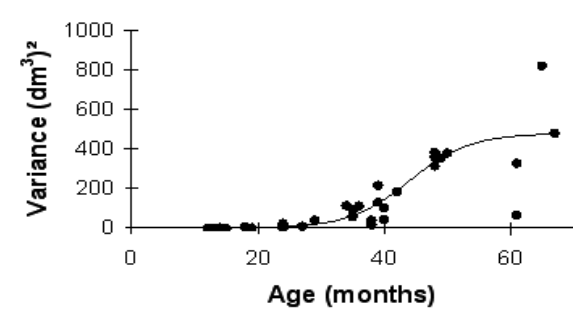

d : $\sigma_{\text {erw }}^{2}$ - Environmental effect

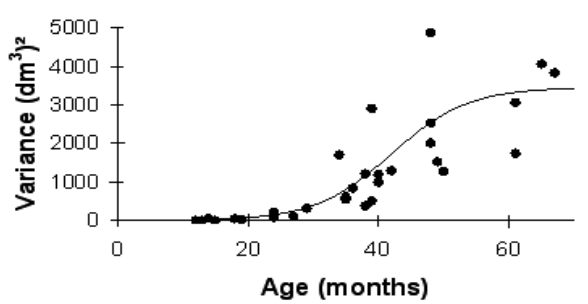

Figure 1. - Trend in variance with age for $E$. urophylla $\mathrm{x}$ grandis for volume growth. The curve was modelled using a nonlinear function (model 2) weighted by the number of crosses per mating design.

a: $\sigma^{2}{ }_{m}-$ male effect,

b: $\sigma_{\mathrm{f}}^{2}$ - female effect,

c: $\sigma^{2}{ }_{m * f}-$ male by female interaction effect.

$\mathrm{d}: \sigma^{2}{ }_{\text {env }}$ - environmental variance estimated by combining within-plot and between-plot environmental variance.

\section{a : narrow sense male heritability}
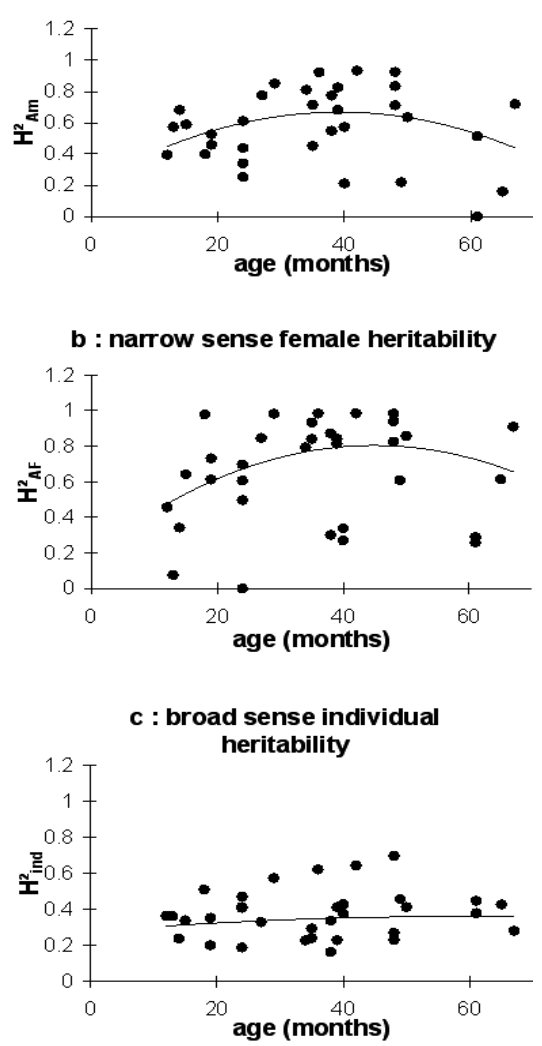

Figure 2. - Trend in heritability with age for volume. The curve was modelled using a polynomial function (model 3) weighted by the number of crosses per mating design.

a: narrow sense male heritability

b: narrow sense female heritability

c: broad sense heritability in the hybrid population. Adjustment with the nonlinear model resulted in relatively high coefficients of determination (0.460 to 0.762$)$ with probabilities lower than 0.001 (Table 2), indicating that the nonlinear model [2] fitted the general trend with acceptable accuracy. However, Figures $1 a$ to $1 d$ illustrate substantial dispersion of values around the curve, highlighting the effect of the factorial design (sample, year, location) on the estimate of variance. The variance trends suggested three periods related to three stages of growth (Fig. 1). During the first period, from planting to 24 months (juvenile stage), variance increased slowly and remained weak. The second period, from 24 to 48 months (mid-rotation stage), was associated with a rapid increase in variance, and the third period from 48 to 72 months (adult stage) corresponded to a plateau or a slow increase in variance.

The male variance was generally smaller than female variance. The $\sigma^{2}{ }_{\mathrm{m}} / \sigma_{\mathrm{f}}^{2}$ ratio decreased with age from one at 12 months to 0.5 at 67 months (results not shown). The dominance to additive variance ratio $\left(\sigma^{2}{ }_{\mathrm{D}} / \sigma_{\mathrm{A}}^{2}\right)$ displayed values higher than one with some estimates close to 3 at the young and adult stages (results not shown).

\section{Trends in heritability}

The three heritabilities did not exhibit marked trends with age (Fig. $2 a, b$ and $c$ ). The coefficient of determination was small $(0.072 ; 0.206 ; 0.116)$ for $h^{2}{ }_{A m}, h^{2}{ }_{A f}$ and $H^{2}{ }_{i n d}$, respectively and the model was only significant for $h^{2}{ }_{A f}(\mathrm{P}=0.031)$ (Table 2), stressing the strong dispersion of estimates around the model and highlighting the impact of sample size on the accuracy of estimates. Modelled female heritability was higher than male heritabil- 
Table 2. - Coefficient of determination $\mathrm{R}^{2}$, coefficients of model (a, b, c, d, e and f), and their standard deviation (between brackets) of the different models used to fit the trends in the various genetic parameters with age Prob: Probability associated with the Fisher test for the significance of the model.

\begin{tabular}{|c|c|c|c|c|c|c|}
\hline $\begin{array}{l}\text { Genetic } \\
\text { parameter }\end{array}$ & model & & \multicolumn{4}{|c|}{ Model parameter variance components } \\
\hline \multirow{3}{*}{$\begin{array}{l}\text { Variance } \\
\text { component }\end{array}$} & \multirow{3}{*}{ Nonlinear (2) } & \multirow{3}{*}{$\begin{array}{l}\text { Prob } \\
\mathrm{R}^{2} \\
\mathrm{a} \\
\mathrm{b} \\
\mathrm{c}\end{array}$} & $\begin{array}{l}\text { Female effect } \\
\sigma_{\mathrm{f}}^{2}\end{array}$ & $\begin{array}{l}\text { Male effect } \\
\sigma_{\mathrm{m}}^{2}\end{array}$ & $\begin{array}{l}\text { Male by female } \\
\text { interaction effect } \\
\sigma_{m^{+} \mathrm{f}}^{2}\end{array}$ & $\begin{array}{l}\text { Environmental } \\
\text { effect } \\
\sigma_{\text {env }}^{2} \\
\end{array}$ \\
\hline & & & $\begin{array}{l}<0.001 \\
0.762 \\
-9.189(2.318) \\
0.209(0.057) \\
479.412(56.123)\end{array}$ & $\begin{array}{l}<0.001 \\
0.460 \\
-8.241(4.478) \\
0.200(0.119) \\
128.578(29.042)\end{array}$ & $\begin{array}{l}<0.001 \\
0.532 \\
-12.858(9.942) \\
0.253(0.211) \\
494.458(101.914)\end{array}$ & $\begin{array}{l}<0.001 \\
0.595 \\
-6.519(2.327) \\
0.147(0.061) \\
3365.309(676.962)\end{array}$ \\
\hline & & & \multicolumn{2}{|c|}{ Model parameter heritability } & & \\
\hline \multirow[t]{2}{*}{ Heritability } & \multirow[t]{2}{*}{ Polynomial (3) } & \multirow[t]{2}{*}{$\begin{array}{l}\text { Prob } \\
\mathrm{R}^{2} \\
\mathrm{a} \\
\mathrm{b} \\
\mathrm{c}\end{array}$} & $\begin{array}{l}\text { Narrow sense female } \\
\text { heritability } \\
\mathrm{h}^{2}{ }_{\mathrm{Af}} \\
0.031 \\
0.206 \\
0.201(0.199) \\
0.026(0.011) \\
-2.824 \mathrm{E}-4(1.423 \mathrm{E}-4)\end{array}$ & $\begin{array}{l}\text { Narrow sense male } \\
\text { heritability } \\
\mathrm{h}^{2} \mathrm{Am} \\
0.326 \\
0.072 \\
0.195(0.192) \\
0.018(0.011) \\
2.26 \mathrm{E}-4(1.38 \mathrm{E}-4)\end{array}$ & $\begin{array}{l}\text { Broad sense } \\
\text { individual } \\
\text { heritability } \\
\mathrm{H}^{2} \text { ind } \\
0.159 \\
0.116 \\
0.173(0.088) \\
0.002(0.005) \\
3.872 \mathrm{E}-7(0.67 \mathrm{E}-5)\end{array}$ & \\
\hline & & & \multicolumn{2}{|c|}{ Model parameter age-age correlation } & & \\
\hline & & & $\begin{array}{l}\text { Female additive effect } \\
\rho_{\text {Af }}\end{array}$ & $\begin{array}{l}\text { Male additive effect } \\
\rho_{\text {Am }}\end{array}$ & $\begin{array}{l}\text { Total genetic effect } \\
\rho_{\mathrm{G}}\end{array}$ & \\
\hline Correlation & $\begin{array}{l}\text { response } \\
\text { Surface (4) }\end{array}$ & $\begin{array}{l}\text { Prob } \\
R^{2} \\
a \\
b \\
c \\
d \\
\text { e } \\
f\end{array}$ & $\begin{array}{l}<0.001 \\
0.316 \\
0.932698 \quad(0.072) \\
5.73 \mathrm{E}-4(34.86 \mathrm{E}-4) \\
5.73 \mathrm{E}-4(34.86 \mathrm{E}-4) \\
-1.30 \mathrm{E}-4(0.45 \mathrm{E}-4) \\
2.70 \mathrm{E}-4(0.37 \mathrm{E}-4) \\
-1.30 \mathrm{E}-4(0.45 \mathrm{E}-4)\end{array}$ & $\begin{array}{l}<0.001 \\
0.522 \\
0.930651 \quad(0.034) \\
10.99 \mathrm{E}-4(17.38 \mathrm{E}-4) \\
10.99 \mathrm{E}-4(17.38 \mathrm{E}-4) \\
-1.12 \mathrm{E}-4(0.23 \mathrm{E}-4) \\
2.13 \mathrm{E}-4(0.20 \mathrm{E}-4) \\
-1.12 \mathrm{E}-4(0.23 \mathrm{E}-4)\end{array}$ & $\begin{array}{l}<0.001 \\
0.599 \\
0.931481(0.042) \\
4.78 \text { E-4(20.36E-4) } \\
4.78 \text { E-4(20.36E-4) } \\
-1.37 E-4(0.26 E-4) \\
2.85 E-4(0.21 E-4) \\
-1.37 E-4(0.26 E-4)\end{array}$ & \\
\hline
\end{tabular}

ity $h^{2}{ }_{A f}=0.90$ compared to $h^{2}{ }_{A m}=0.70$ for the highest point of the curve, possibly explained by higher variability of the female population (Fig. 1a,b). Heritability calculated on the basis of individual phenotype was smaller $\left(H^{2}{ }_{i n d}=0.45\right.$ for the highest point of the curve), because the environmental effects are preponderant at an individual level (Fig. 2c).

\section{Age-age correlation}

Our modelling of age-age correlation with a response surface gave acceptable results, with the coefficient of determination around 0.3 for the female effect, 0.5 for the male effect, and 0.6 for the total genetic effect. All three models were significant (Table 2). As expected, the correlation of the male and female additive, and total genetic effects showed a marked increase (Fig. $3 a, b$ and c). After 36 months, the values were higher than 0.8 . These high age-age genetic correlations confirm previous findings in eucalyptus populations. (BOUvET, 1995; OsoRIo et al., 2003)

\section{Genetic gain and optimal age for selection}

Although all the models for heritability were not significant (Table 2), we used the equation [5] to calculate genetic gain. For males (Fig. 4a) and females (Fig. 5a), the genetic gain increased with age and reached an optimum around 54 months. The genetic gain for females was higher than that for males $(14 \%$ and $6 \%$ respectively for $30 \%$ selection intensity at 54 months). This may be explained by the higher genetic variability and heri- tability of the female breeding population (Fig. 1 and 2). The results are presented with two moderate intensities of selection (30 and $50 \%$ of trees selected are used for the second cycle of RRS) so as to prevent genetic erosion in further breeding cycles (GALLAIS, 1989). For the males and females, the efficiency of selection " $E$ " was close to one at 30 and 42 months respectively (Fig. $4 b$ and $5 b$ ), suggesting that this age is appropriate for screening of males and females. Values higher than one and trend of the curve after 42 months showed that the optimal age of selection is 54 months and not 72 months, i.e. the rotation age. The decrease in the gain efficiency between 54 and 72 months may be explained by a decrease in heritability with age between 54 and 72 months (Fig. $2 a$ and $2 b$ ).

The efficiency of selection per time unit " $E$ ” decreased rapidly with age, especially before 18 months, but was higher than one from 6 up to 72 months for male and female selection (Fig. $4 c$ and $5 c$ ). For example, at 24 months, the genetic gain per time unit was 3 (2.5) times higher than the gain at adult stage for male and female selection respectively.

For the selection of individual trees (ortets), the results suggest that considerable genetic gain can be achieved (40 and $60 \%$ of the population mean at 72 months for an intensity of selection of 5 and $1 \%$, respectively) (Fig. 6a). This result is to be expected because of the marked variability within the Eucalyptus hybrid population which had not undergone previous breeding 
a : male additive effect

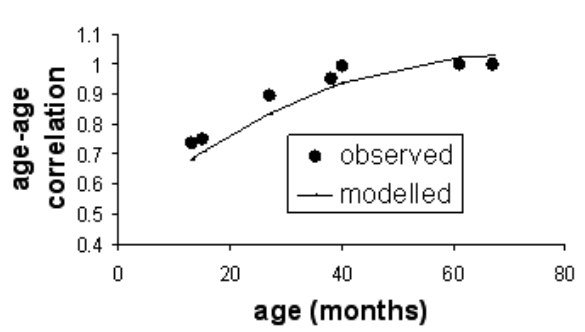

b : female additive effect

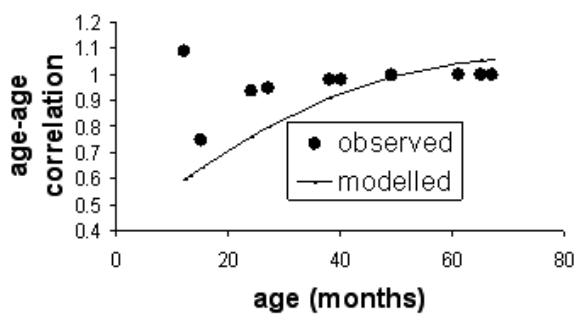

c : total genetic effect

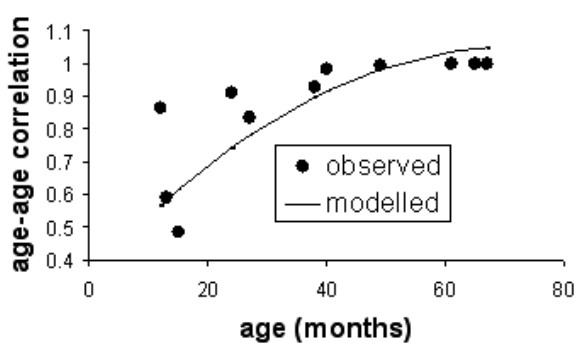

Figure 3. - Trend in age-age correlation with age for volume. The curve was modelled using a response surface (model 4) function weighted by the number of crosses per mating design. a: male additive age-age correlation

b: female additive age-age correlation

c: total genetic age-age correlation

cycles, the high selection intensity (1 and $5 \%$ of trees selected) and the exploitation of both additive and dominance effects. The efficiency of selection " $E$ " was lower than one from 6 up to 72 months suggesting a better efficiency of selection at adult stage (Fig. 6b). However, the efficiency of selection per time unit " $E$ " was higher than one from 6 up to 72 months (Fig. 6c). At 24 months, the genetic gain per time unit was 1.5 times higher than the gain at adult stage.

\section{Discussion}

Although calculation of genetic gain and determination of optimal age for selection in programmes using both additive and non-additive effects have been studied in various Eucalyptus breeding programmes (VOLKER, 1995; REZENDE and DE RESENDE, 2000; LEE et al., 2007; RETIEF and STANGER, 2007) new results are needed to improve our understanding of the influence of additive and non additive effects in growth traits and their con- a : m ale selection

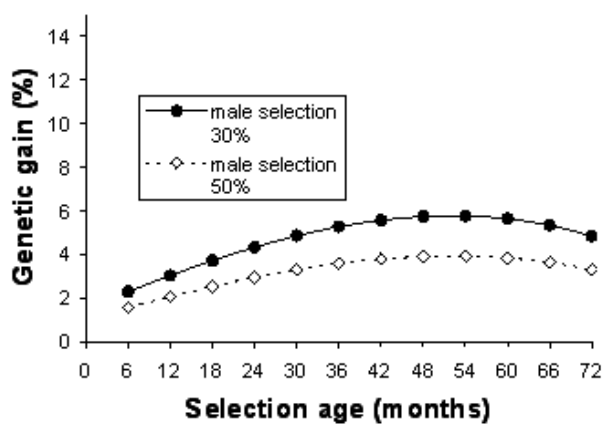

b : $m$ ale selection

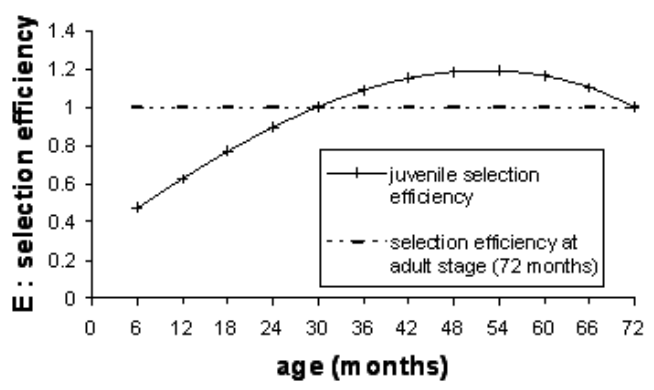

c : male selection

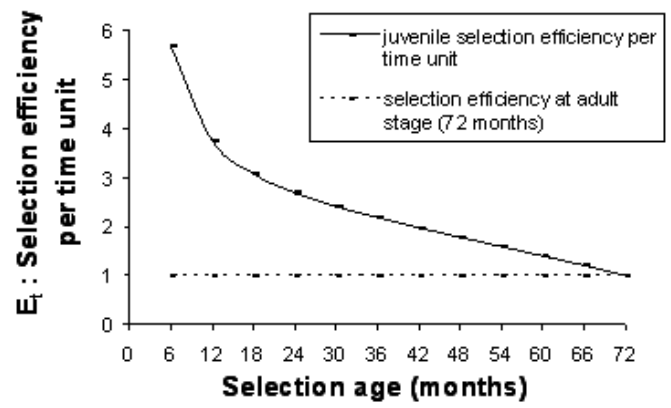

Figure 4. - Trends in genetic gains with age (a), in the efficiency of selection (b) and in the efficiency of selection per time unit (c) for male selection.

sequences for the optimal age for selection. Our study provides new empirical results in the context of tree breeding, especially for Eucalyptus, one of the most widely planted tree genera in tropical and warm temperate zones.

\section{Trends in variance components}

The variance trends suggested the presence of three periods. During the first period, from planting to 24 months, variance increased slowly and remained weak. This may be explained by growth being directed towards exploitation of the environment by the seedling's root system. During this period, the root system develops rapidly in Eucalyptus in the conditions prevailing in the Congo (BoullLET et al., 2002). During the second period, from 24 to 48 months, there was a rapid increase in 
variance, corresponding to a period of increasing growth and competition. During the third period, the rate of increase in variance decreased, corresponding to a slower growth once competition is established. This analysis clearly showed that variance expression is related to growth and competition, as suggested by Franklin's model (FRANKLIN, 1979) in other species. Variance after 65 months of age could not be assessed in theses experiments because of the rotation age of Eucalyptus trials. However, a longer study (150 months) with clones using wide spacings, (BouvET, 1991), indicated that variance increases slowly with age in Eucalyptus stands in the Congo, but that the coefficient of variation remains relatively stable over time (very small increase after 50 months of age). We can suppose the same trend after 65 months in our present field trials as we planted with the same wide spacing (625 trees/ha), corresponding to the spacing used in commercial plantations to prevent strong competition

The analysis indicates a $\sigma_{\mathrm{D}}^{2} / \sigma^{2}{ }_{\mathrm{A}}$ ratio higher than one from planting to 60 months of age. These results are consistent with previous studies with height and circumference on the same sample (BOUVET et al., 2009). The authors suggest that this slight preponderance of the dominance effect can be explained by the effect of the phenotypic selection of female and male parents (Bouvet and Vigneron, 1996) and the expression of the overdominance in the case of hybrids (BIRCHLER et al., 1990), especially when they are planted in marginal zones where hybrid vigour plays an important role in

\section{a : female selection}

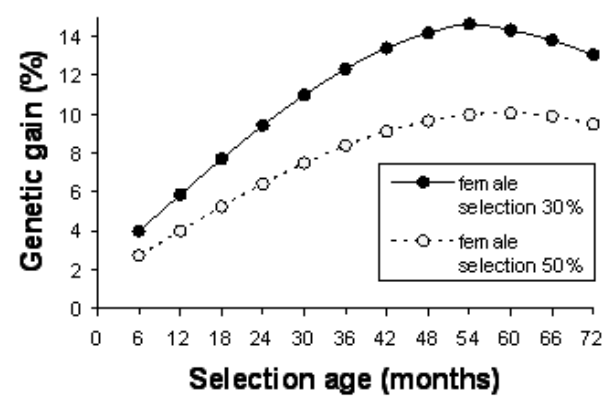

b: female selection

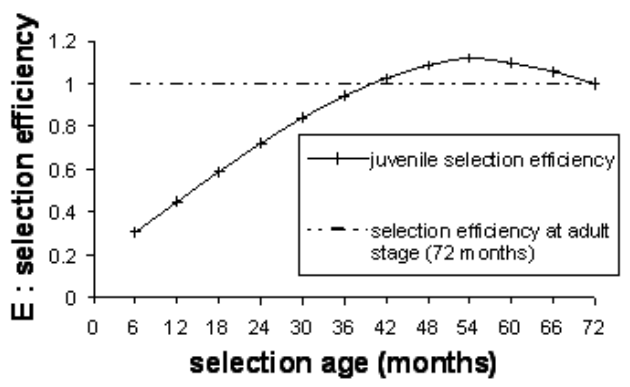

c : female selection

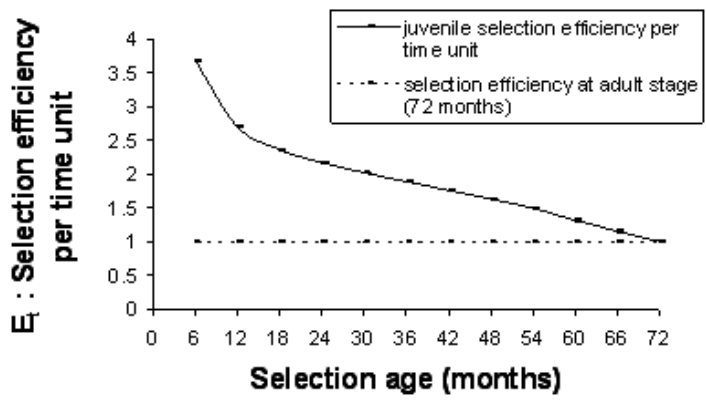

Figure 5. - Trends in genetic gains with age (a), in the efficiency of selection (b) and in the efficiency of selection per time unit (c) for female selection. a : individual (ortet) selection

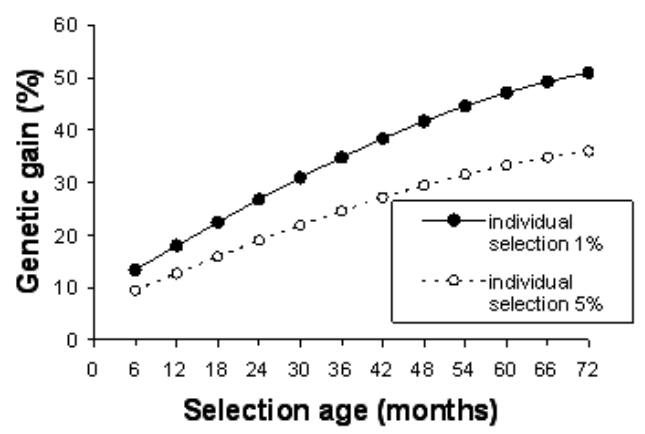

b : individual (ortet) selection

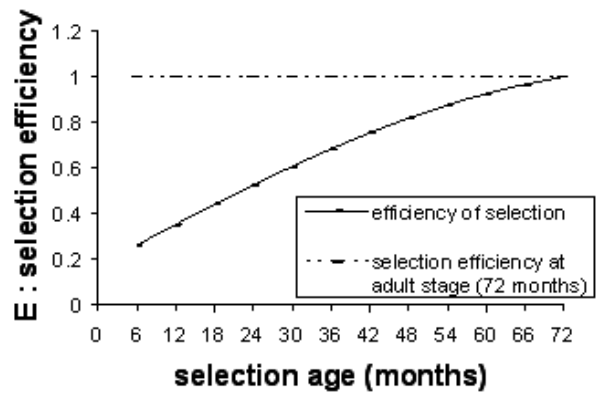

c : individual (ortet) selection

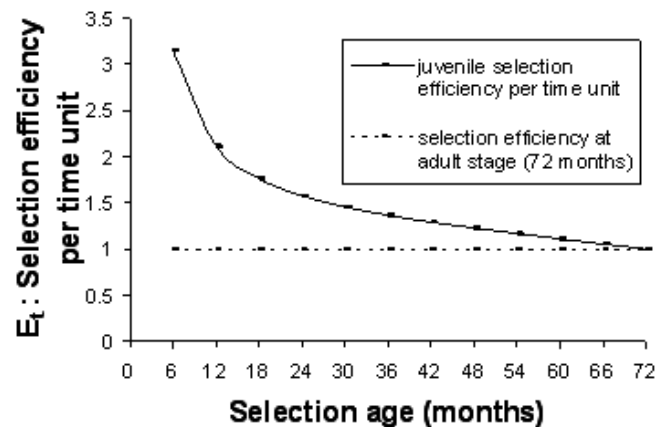

Figure 6. - Trends in genetic gains with age (a), in the efficiency of selection (b) and in the efficiency of selection per time unit (c) for individual (ortet) selection. 
adaptation and performance (POTTS and DUNGEY, 2004; DALE and DiETERS, 2007).

\section{Heritability of volume}

Our results showed that narrow and broad sense heritabilities varied moderately during the young and mature stages (Fig. 2 and Table 2). This result is consistent with studies on some tropical and temperate species (BorRALHO et al., 1992a; MARQUES et al., 1996; Patinot-VAlera and Kageyama, 1995; Wei and BorralHO, 1998). The absence of trends may be due to the short period taken into account in stand development. Although our trials represented good testing conditions (effective weed control, fertilisation), the individual broad sense heritabilities for volume, $H^{2}$ ind were significant but relatively small ( 0.35 on average) compared to other studies (VOLKER et al., 1990; BORRALHO et al., 1992b; TibBits and Hodge, 1998; SANuHeZA et al., 2002). This may be explained by the strong micro-environmental effect due to mortality during tests (Table 1), leading to a variable competition effect among trees, especially for growth traits (GALLAIS, 1989; FALCONER and MACKAY, 1996). Conversely, our estimates of narrow sense heritability for parent selection, $h^{2}{ }_{\text {Am }}$ and $h^{2}$, are quite high compared with the same studies. The large number of progenies per parent combined with the good testing conditions and the four replications used in most of the trials may account for this result.

\section{Consequences for genetic gain and optimal age of selection}

In the context of the reciprocal selection scheme, the objective is to select parents for recombination for the next breeding cycle and to select individuals (ortets) for the production of clones. Modelling of age-related trends in genetic parameters has been used to calculate genetic gain with different selection intensities, and to determine the optimal age for selection.

The optimal age for selection has been reported in different breeding programmes for short rotation plantations: 12 months for height and circumference in E. urophylla (WEI and BORRALHO, 1998), 30 months for circumference (MARQUES et al., 1996) and 36 months for $E$. grandis (OsorIo et al., 2003). In our study, the efficiency " $E$ " indicated an optimal age of 54 months for juvenile selection for males, females and mature age for ortets. However, the efficiency per time unit " $E$ " showed that juvenile selection is more efficient than adult selection whatever the age for females, males and ortets especially before two years. A similar result in " $E$ " trend was observed in previous study in Sitka Spruce (LEE et al., 2001). The efficiency of juvenile selection is explained by the high heritability at younger stages and the strong age-age genetic correlation. In preliminary analyses, BOUVET (1995) suggested that 36 months old could be an appropriate age for juvenile selection. Our more global results offer new elements to adjust the optimal age of selection. This age should be decided by taking into account the trend in efficiency of selection per time unit with age for volume, but also the efficiency of selection of others traits important for eucalyptus breeding (wood properties, diseases resistance).
Equations 4 and 5 show that increasing heritability and age-age correlations can increase the genetic gain. Numerous studies have analysed ways to increase these parameters, for example by changing competition (by increasing plantation density) in Eucalyptus progeny tests (BOUvET et al. 2003; 2005). These authors showed that increased competition can improve genetic gain, but the relationship depends on the field design (single tree plot versus square plot) and on the genotype (families versus individuals). For the selection of individual trees (ortets) the use of an experimental design with a density, fertilising regime and silviculture similar to the commercial plantation is recommended.

In this study, we also considered another critical parameter, i.e. the intensity of selection. The intensity of selection for females and males was not very strong (two scenarios with 30 and $50 \%$ of trees selected for the second RRS cycle). This moderate intensity prevents genetic erosion in further breeding cycles, which is critical for long-term breeding (GALLAIS, 1989). A moderate intensity of selection on growth traits is also recommended in order to maintain breeding potential for other traits such as wood properties. Due to the absence of a strong correlation between basic density and growth traits, (Bouvet, 1995; Bouvet and BaIlleres, 1995; TibBits and HodGe, 1998; SANHUEZA et al., 2002) a broad genetic base is required to increase the probability of selecting individuals with combinations of favourable traits. For individual trees, we chose a stronger selection intensity ( 1 and $5 \%$ of trees selected) leading to considerable genetic gain, given that the objective is to create clonal varieties. As with the parents, the selection intensity should be lower in a multi-trait approach especially with uncorrelated traits (such as basic density) in order to detect ideotypes (BARADAT et al., 1994).

\section{Conclusion}

The breeding strategy implemented in the Congo was chosen to optimise the selection process based on both additive and non-additive effects. The importance of both additive and dominance effects in the expression of volume, based on the consistent sampling of parent trees, families and individuals, confirmed that the reciprocal recurrent selection scheme was a relevant choice for the improvement strategy. The objective of our study was both to predict genetic gain for volume according to different selection scenarios, and to propose a frame to determine (and adjust) the optimal age for selection using the information obtained at the end of the first cycle of the breeding strategy. The study shows that juvenile selection per time unit of parents and clones for volume can be more efficient than selection at rotation age in the Congolese eucalyptus breeding programme.

\section{Acknowledgements}

We are grateful to the three founders of the UR2PI (Unité de Recherche sur la Productivité des Plantations Industrielles) in the Republic of Congo for having supported this research over a period of several years: the Ministry of Research of the Republic of the Congo, the plantation company (Eucalyptus Fibre of the Congo) EFC and 
the CIRAD. We are grateful to the UR2PI staff, especially the monitoring team, for providing information and data on the experimental designs. We are grateful to the three anonymous reviewers for their suggestions and comments, which significantly improved the manuscript.

\section{References}

Adams, W. T., S. N. Aitken, D. G. Joyce, G. T. Howe and J. VARGAS-HERNANDEZ (2001): Evaluating Efficacy of Early Testing for Stem Growth in Coastal Douglas-fir Silvae Genetica 50: 167-175.

Baradat, P., T. LABBe and J.-M. Bouvet (1994): Conception d'index pour la sélection réciproque récurrente: aspectes génétiques, statistiques et informatiques. Pages 101-150. In: Traitements statistiques des essais de sélection. Stratégies d'amélioration des plantes pérennes. Actes du séminaire de biométrie et génétique quantitative. CIRAD, Montpellier, France.

BECKeR, W. A. (1984): Manual of Quantitative Genetics, $4^{\text {th }}$ edn, p 188 Academic Enterprises, Pullman, Washington.

Birchler, J. A., H. Yao and S. Chudalayandi (2006): Unraveling the genetic basis of hybrid vigor. P Natl Acad Sci USA 103: 12957-12958.

Borralho, N. M. G., P. J. Kanowski and P. P. Cotterill (1992a): Genetic control of growth of Eucalyptus globulus in Portugal. I Genetic and phenotypic parameters, Silvae Genetica 41: 39-45.

Borralho, N. M. G., P. J. Kanowski and P. P. Cotterill (1992b): Genetic parameters and gain expected from selection for dry weight in Eucalyptus globulus ssp. Globulus in Portugal. Forest science 38: 80-94.

Bouillet, J. P., R. SAFou-Matondo, J.-P. LAClau and J. RANGER (2002): Changes with age in the spatial localisation of roots of an Eucalyptus clone in the Congo. Impact on water uptake ability. Forest Ecology and Management. 171: 43-57.

BouveT, J.-M. (1982): Pollinisation contrôlée des Eucalyptus et production d'hybrides en République Populaire du Congo : Mémoire de 3ème année ENITEF.

BouvET, J.-M. (1991): Analyse des tests clonaux d'eucalyptus hybrides, réflexions sur la méthodologie de sélection. Report of Master of sciences, INAPG, Paris.

Bouvet, J. M. (1995): Evolution de la variabilité avec l'âge et corrélation juvénile-adulte dans les populations d'eucalyptus. Thèse de doctorat INAPG. 296 p.

Bouvet, J.-M. and H. BAILleRes (1995): Expression of some Growth and Wood properties Traits Among Eucalyptus urophylla $\mathrm{x}$ grandis clones in Congo. Proceedings de la conférence CRCTHF-IUFRO: Eucalypt plantation: improving fibre yield and quality. Hobart, Australie 19-24 février 1995, pp. 89-92.

Bouvet, J.-M. and P. VIGNERON (1996): Variance Structure in Eucalyptus Hybrid Populations, Silvae Genetica 45: 2-3.

Bouvet, J. M., P. Vigneron, A. SAyA and R. Gouma (2003): Trends in variances and heritabilities with age for growth traits in eucalyptus spacing experiments. Silvae gentica 52, 3-4: 121-133.

Bouvet, J. M., P. Vigneron and A. SAYA (2005): Phenotypic plasticity of growth trajectories and ontogenic allometry in response to density in eucalyptus clones and families. Annals of Botany 96: 811-821.
Bouvet, J. M., P. Vigneron and A. Saya (2009): Trends in additive, dominance and environmental effects with age for growth traits in Eucalyptus hybrid populations. Euphytica 165: 35-44.

Dale, G. and M. Dieters (2007): Economic returns from environmental problems: Breeding salt- and droughttolerant eucalypts for salinity abatement and commercial forestry. Ecological Engineering 31 (2007) 175-182.

De Assis, T. F. (2000): Production and use of eucalyptus hybrids for industrial purposes. Pages 63-74. In: H. S. Dungey, M. J. Dieters and D. G. Nikles, editors. Hybrid Breeding and Genetics of Forest Trees Proceedings of QFRI/CRC-SPF Symposium. Department of Primary Industries, Brisbane, Noosa, Queensland, Australia.

FALCONER, D. S. and T. F. C. MACKAY (1996): Introduction to quantitative genetics. New York; Longman Scientific and technical, $4^{\text {th }}$ ed., $464 \mathrm{p}$.

Franklin, E. C. (1979): Model relating levels of genetic variances to stand development of four North American conifers. Silvae Genetica 28: 207-212.

GaLlais, A. (1989): Théorie de la sélection en amélioration des plantes. Editions Masson, Paris. 589 p.

Johnson, G. R., R. A. SNiEzko and N. L. MANDEL (1997): Age trends in Douglas-fir genetic parameters and implication for optimal selection age. Silvae Genetica 46: 349-358.

Lee, S. J., J. C. Woolliams, J. A. SAmuel and D. C. MalCOM (2002): A study of population variation and inheritance in Sitka spruce: III. Age trends in genetic parameters and optimum selection ages for wood density, and genetic correlations with vigour traits. Silvae Genetica 51: 143-151.

LeE, D. J., J. R. Huth, J. T. Brawner and G. R. Dikinson (2007): Relative performance of Corymbia Hybrids and parental open-pollinated families in subtropical Queensland. In conference on "Eucalypts and diversity: balancing productivity and sustainability”. Durban 22 to $26 / 10 / 2007$.

Lopez, G. A., B. M. Potts, G. W. Dutkowski, J. M. RODRIGUEZ TRAVERSO (2001): Quantitative genetics of Eucalyptus globulus: affinities of land race and native stand localities. Silvae Genetica 50: 244-252.

Marques, O. G., H. B. Andrade and M. A. P. Ramalho (1996): Assessment of the early selection efficiency in Eucalyptus cloeziana F. MUELL. in the northwest of Minas Gerais state (Brazil). Silvae Genetica 45: 359-361.

Meyers, R. H. and D. G. Montgomery (2002): Response surface methodology - Process and product optimization using designed experiments. Wiley series in probability and statistics. Wiley. $824 \mathrm{P}$.

Osorio, L. F., White, T. L and D. A. Huber (2003): Ageage and trait-trait correlations for Eucalyptus grandis Hill ex Maiden and their implication for optimal selection age and design of clonal trials. Theoretical and Applied Genetics 106: 735-743.

Patinot-VAlera, F. and P. Y. Kageyama (1995): Parametros geneticos y espaciamieto en progenie de Eucalyptus saligna Smith. Research Paper IPEF, Piracicaba (48/49): 61-76, jun. Dez 1995.

PotTs, B. M. and H. S. Dungey (2004): Interspecific hybridization of Eucalyptus: key issues for breeders and geneticists. New Forests 27: 115-138. 
Rezende, G. D. S. P. and M. D. V. De Resende (2000): Dominance effects in Eucalyptus grandis, Eucalyptus urophylla and Hybrids. In: Dungey, H. S., DiETERS, M. J. and NikLES, D. G. (Eds.).Hybrid Breeding and Genetics of Forest Trees. Proc. QFRI/CRC-SPF Symposium, Noosa, Queensland, Australia. April 2000. p93-100.

Retief, E. C. L. and T. K. Stanger (2007): Genetic parameters of pure and Hybrid populations of Eucalyptus grandis and Eucalyptus urophylla and implications for Hybrid breeding strategy. In: conference on "Eucalypts and diversity: balancing productivity and sustainability”. Durban 22 au 26/10/2007

SAnuheza, R. P., T. L. White, D. A. Huber and A. R. GrifFIN (2002): Genetic parameters estimates, selection indices and predicted genetic gains from selection of Eucalyptus globulus in Chile. Forest Genetics 9: 19-29.

SAS InstituTE INC. (1990): SAS/STAT user's guide, release 6.03 edn. SAS Institute Inc, Gary, North Carolina.

TibBits, W. and G. Hodge (1998): Genetic parameter and breeding value predictions for Eucalyptus nitens wood fiber production traits. Forest Science 44: 587.

Velilla, E. L., G. W. Dutkowski and R. P. SANuheza (2007): Genetic analysis of Eucalyptus nitens: Genetic parameters and breeding value predictions In conference on "Eucalypts and diversity: balancing productivity and sustainability". Durban 22 au 26/10/2007.

VERRYN, S. D. (2000): Eucalyptus hybrid breeding in South Africa. In: Dungey, H. S., Dieters, M. J. and NikLES, D. G. (Eds.). Hybrid Breeding and Genetics of Forest Trees. Proc. QFRI/CRCSPF Symposium, Noosa, Queensland, Australia. April 2000. p191-199.
Vigneron, P. (1991): Creation et amelioration de varieties hybrides d'Eucalyptus au Congo. In: SchÖNAU, A. P. G. (Ed.). The Role of Eucalypts. Proc. IUFRO Symposium on Intensive Forestry: Durban, South Africa. September 1991. p345-360.

Vigneron, P. and J.-M. Bouvet (1997): Eucalyptus In Breeding of tropical plants. In: CHARRIER. A., JACQUOT, M., Hamon, S., Nicolas, D. (Ed.) Cirad, Orstom, Montpellier, Collection Repères.pp. 267-290.

Vigneron, P., J. M. Bouvet, R. Gouma, A. Saya, J. M. Gion and D. VerhaEgen (2000): Eucalypt hybrids breeding in Congo. Pages 14-26. In: H. S. Dungey, M. J. Dieters, and D. G. NIKLES, editors. Hybrid breeding and genetics of forest trees. Proceedings of QFRI/CRCSPF Symposium. Department of Primary Industries, Brisbane, Noosa, Queensland, Australia.

VOLKER, P. W. (1995): Evaluation of Eucalyptus nitens x globulus for commercial forestry. Pages 222-225. In: B. M. PotTs, editor. Eucalypt plantations: Improving fibre yield and quality. CRCTHF-IUFRO, Hobart, Australia.

Volker, P. W., C. A. Dean, W. N. Tibbits and I. C. RaVenWOOD (1990): Genetic parameters and gains expected from selection in Eucalyptus globulus in Tasmania. Silvae Genet 39: 18-21.

Wei, X., and N. M. G. Borralho (1998): Genetic control of growth traits of Eucalyptus urophylla S. T. BLAKE in South East China. Silvae Genetica 47: 158-164.

\title{
Genetic Parameters and Genotype by Environment Interactions for Green and Basic Density and Stiffness of Pinus radiata D. Don Estimated Using Acoustics
}

\author{
By B. Wielinga ${ }^{1), 5)}$, C. A. RAymond ${ }^{2,4), *}$, R. JAmes ${ }^{1)}$ and A. C. Matheson ${ }^{3), 4)}$ \\ (Received $5^{\text {th }}$ February 2008)
}

\footnotetext{
1) Fenner School of Environment and Society, Australian National University, Canberra ACT 0200.

${ }^{2}$ ) Forests NSW, PO Box 46, Tumut NSW 2720. Current Address: Centre for Plant Conservation Genetics, Southern Cross University, PO Box 157, Lismore NSW 2480.

3) Current Address: Post Retirement Research Fellow, CSIRO Plant Industry, PO Box 1600, Canberra ACT 2601.

4) Visiting Fellow, Fenner School of Environment and Society, Australian National University, Canberra ACT 0200.

5) Current Address: Carter Holt Harvey Wood Products Australia, PO Box 330, Mount Gambier SA 5290.

*) Corresponding Author, E-mail: Carolyn.raymond@scu.edu.au
}

\begin{abstract}
Genetic parameters and genotype by environment interactions for wood properties of 13-year-old Pinus radiata were determined by sampling two progeny trials on contrasting sites in the southern slopes of New South Wales, Australia. Heritability of green and basic density were determined together with dynamic modulus of elasticity (MOE) measured using TreeTap.

The phenotypic variance in MOE (CV 17-18\%) was almost three times that of basic density. MOE and basic density were highly heritable at both sites $\left(h^{2} 0.57 \&\right.$ 0.79 for MOE \& 0.59 and 0.85 for density). There was a
\end{abstract}

